Linha D'Água (Online), São Paulo, v. 30, n. 2, p. 9-16, out. 2017

\title{
NELLY NOVAES COELHO: UMA VIDA DEDICADA À LITERATURA
}

\section{NELLY NOVAES COELHO: LIFE DEDICATED TO LITERATURE}

\author{
Maria Zilda Cunha* \\ Universidade de São Paulo, São Paulo, SP, Brasil \\ Cristiano Camilo Lopes** \\ Universidade Presbiteriana Mackenzie, São Paulo, SP, Brasil
}

\begin{abstract}
Resumo: Neste artigo, propõe-se homenagear a professora Nelly Novaes Coelho destacando aspectos da sua biografia que vão desde a sua infância e formação até sua atuação como escritora, professora e crítica de arte. Para cumprir esse objetivo, o texto está segmentado em quatro partes: na primeira, apresentam-se os pilares da formação da professora Nelly, destacando-se seu gosto pela arte literária desde a infância; na segunda, descreve-se sua ałuaç̃ão como docente universitária e sua consequente acção no ensino da literatura; na terceira parte, impõem-se suas contribuições para literatura infantil e para a literatura produzida por mulheres, dois campos que Nelly se debruçou com afinco para a producção de material teórico na área de literatura; e, por fim, na quarta parte, destacam-se a perspectiva da professora sobre a literatura no século XXI. Listam-se também, neste trabalho, toda a produção bibliográfica da autora bem como os prêmios recebidos no Brasil e no exterior.
\end{abstract}

Palavras-chave: Nelly Novaes Coelho; literatura infantil e juvenil; crítica literária; literatura e ensino; escritoras brasileiras.

Abstract: This article aims to pay a tribute to the professor Nelly Novaes Coelho highlighting aspects of her biography that range from her childhood and training to her role as a writer, professor and art critic. In order to fulfill this objective the text is segmented in four parts: in the first one, the pillars of Professor Nelly's training are presented, being emphasized its taste for the literary art since her childhood; in the second one, we describe her performance as a university professor and its consequent action in the teaching of literature. In the third part, we expose her contributions to children's literature and to the literature produced by women, two fields that Nelly has worked hard on in order to produce theoretical material in the field of literature; Finally, in the fourth part, the professor's perspective on literature in the $27^{\text {st }}$ century is emphasized. We also list, in this work, all the bibliographical production of the author as well as the prizes received in Brazil and abroad.

Keywords: Nelly Novaes Coelho; Children's Literature; Critics Literature; Teaching Literature; Brazilian Women Writers.

* Professora doutora da Universidade de São Paulo - USP, São Paulo, SP, Brasil; mariazildacunha@hotmail.com

** Professor doutor da Universidade Presbiteriana Mackenzie - UPM, São Paulo, SP, Brasil; cristianoclopes@hotmail.com 
Linha D'Água (Online), São Paulo, v. 30, n. 2, p. 9-16, out. 2017

A vida é também para ser lida. Não literalmente, mas em seu supra-senso. E a gente, por enquanto, só a lê por tortas linhas.

Guimarães Rosa

\title{
Introdução
}

\begin{abstract}
Estar com Nelly Novaes Coelho é sempre uma preciosa oportunidade de aprendizado, quer pelo privilégio de ser seu aluno ou aluna nos bancos universitários, quer como ouvinte em seminários e eventos culturais ou simplesmente em conversas informais no dia-a-dia. Na verdade, ensinar e com generosidade incondicional transmitir seus conhecimentos e suas descobertas teóricas e analíticas em Literatura tem sido o grande propósito de sua vida. (PAPES, 2010)
\end{abstract}

Nelly Novaes Coelho nasceu em São Paulo, em 1922, logo após a efervescência da semana da Arte Moderna. Sob o signo das artes, ela cresceu fascinada pelo universo da música e da literatura. Seu desejo, desde muito jovem, era ser pianista, como sua tia Guiomar Novaes (1894-1979) ${ }^{1}$. Esta não cansava de elogiar o talento da sobrinha. Frequentou o Conservatório Dramático e Musical de São Paulo e obteve por mérito uma bolsa em 1942, para estudar na Itália, mas foi impedida em razão do recrudescimento da Segunda Guerra Mundial (1939-1945).

A inclinação pela literatura Nelly manifestou desde a infância, em especial, no que se referia à atividade leitora. Um episódio era sempre revelado nas disciplinas que ministrava na USP: quando menina, no colégio, durante as aulas de bordado, enquanto a maioria das alunas bordava, alguém teria de ler um livro, tarefa que ela assumia prazerosamente. Do título ela não se lembrava, mas recordava haver numa das histórias uma personagem engraçada que falava inglês. Nelly assumia a personagem e sua fala, mesmo que nada soubesse desse idioma (todos pediam que fosse sempre ela a ler). Mas "Nelly também precisa bordar", dizia a madre. Sorrindo, ela continuava: "Então, eu bordava em casa para poder ler sempre na sala, era do que eu gostava: de ler".

Como leitora voraz, nunca escondeu sua paixão pela literatura. Ao ingressar em Letras em 1955, na Universidade de São Paulo, já possuía singular repertório

A quem tive o prazer e a honra de conhecer e ouvir, era vizinha e amiga de meus tios. 
Linha D'Água (Online), São Paulo, v. 30, n. 2, p. 9-16, out. 2017

bibliográfico composto por clássicos da literatura nacional e estrangeira e já denotava entusiasmo por pensadores como Kant, Nietzsche, Heidegger, Spengler, entre outros. Cursou o doutorado, na mesma universidade, entre os anos de 1964 e 1967, usufruindo de uma bolsa concedida pela Fundação Calouste Gulbenkian. Realizou em Portugal extensa pesquisa que resultou na tese Jardim das Tormentas: Gênese da fição de Aquilino Ribeiro (publicada pelas edições Quíron, em 1973). Iniciou-se, assim, um percurso bastante intenso de reflexões voltadas os estudos literários, com atividades de pesquisa, crítica e ensino de Literaturas Portuguesa, Brasileira, Estudos Comparados, além de Literatura Infantil e Juvenil que lhe exigiram trânsito interdisciplinar. Todas as suas atividades refletem o perfil sério e comprometido de professor que se situa como especialista de referência em sua área de atuação.

Em 1961, a professora Nelly assumiu a cadeira de Teoria da Literatura da Faculdade de Filosofia Ciências e Letras de Marília, São Paulo, onde permaneceu até 1972. Concomitantemente, em 1965, ingressou como professora assistente de Espanhol e de Língua Portuguesa, na Faculdade de Filosofia Letras Ciências Humanas da Universidade de São Paulo. Em 1971, atuou como professora convidada em curso de Literatura Portuguesa na Universidade de Lisboa, e em 1979, ofereceu em nível de pós-graduação a disciplina Literatura e Cultura Brasileira, na University of California/ Los Angeles, pela Fulbright Foundation - USA. Além disso, ministrou cursos esporadicamente em universidades em vários outros estados brasileiros.

Para além das universidades, não podemos esquecer a importância de sua atuação permanente na orientação de professores cuja tarefa era o trabalho com leitura de crianças e jovens, pilar da formação de seres humanos. Foram inúmeras aulas, minicursos, palestras, cursos de extensão, conferências, mesas redondas, entrevistas, participação em seminários e congressos. Nelly foi uma das mais respeitadas estudiosas da Literatura na Universidade brasileira. Para Nelly, a utopia resultaria do próprio homem, de cuja palavra depende a inauguração de uma outra era. A Literatura faculta resgatar fatos que, ao longo do tempo, marcaram a caminhada humana, seus anseios, seus dramas, suas paixões. 
Linha D'Água (Online), São Paulo, v. 30, n. 2, p. 9-16, out. 2017

\section{O Século XX: o desafio do ensino da literatura e a formação dos leitores}

Nos anos 80 do século XX, Nelly percebeu que duas áreas estavam se impondo e careciam de especial atenção da pesquisa e da crítica. A primeira delas, a Literatura Infantil e Juvenil, que, segundo Nelly, apontava os valores da uma nova mentalidade. Emergiam excelentes escritores e excelentes ilustradores. A pesquisadora ressaltou a importância da dinâmica histórica da Literatura em geral, em paralelo com a da Literatura Infantil: "[...] em essência, sua natureza é a mesma da que se destina aos adultos. As diferenças que a singularizam são determinadas pela natureza do seu leitor/receptor: a criança" (COELHO, 2000, p. 29).।

Enfatizou a necessidade da formação cultural sólida do educador e do pesquisador da área, segundo uma mentalidade crítica. ${ }^{2}$ Nesse contexto, sua figura impõe-se como fundadora da área de Literatura Infantil e Juvenil na USP, criando disciplinas de graduação, cursos de extensão e cursos de pós-graduação. Sob sua orientação, ganharam força projetos de mestrado e doutorado ${ }^{3}$. São inúmeros os trabalhos acadêmicos, dissertações e teses de doutorado nessa área que, hoje, acothe o estudo das complexas intersecções entre a produção literária para crianças e jovens e o universo hipermidiático contemporâneo. Sua atuação estendeu para além dos muros da universidade:

Tais trabalhos são de fundamental importância para a pesquisa e os estudos literários realizados na graduação e pós-graduação da FFLCH da Universidade de São Paulo onde ela criou a disciplina Literatura Infantil e Juvenil (Brasil e Portugal), cujos objetivos estenderam-se depois a muitas outras universidades, a outras áreas do conhecimento, a escolas do ensino infantil e fundamental na tarefa de formação do ser e do leitor. (PAPES, 2010)

2 Professora Dra Nelly Novaes Coelho consolida suas ideias escrevendo profícuo material que constitui um panorama histórico da Literatura Infantil e Juvenil, o livro abarca as origens Indo-europeias ao Brasil contemporâneo. Livro essencial nos cursos de Letras e Educação.

COELHO, Nelly Novaes. Panorama histórico da literatura infantil e juvenil. Das origens hindo-europeias ao Brasil contemporâneo. 5 ed., Barueri: Manole, 2010.

3 Orientações concluídas: 16 metrados e 18 doutorados. 
Linha D'Água (Online), São Paulo, v. 30, n. 2, p. 9-16, out. 2017

A segunda é a Literatura escrita por mulheres: Nelly notou o pouco registro que havia dessas escrituras e passou a solicitar das autoras de vários estados brasileiros os respectivos dados bibliográficos e biográficos. Iniciou, assim, uma pesquisa extensa sobre 1400 escritoras brasileiras, publicada em dois dicionários A Literatura Feminina no Brasil Contemporâneo, em 1993, e Dicionário Crítico de Escritoras Brasileiras, em 2002 e 2011. Ambos constituem produção de matiz crítica e não apenas bibliográfica. São encontrados verbetes que vão de oito linhas a extensão sete páginas. Seu trabalho revela a leitura cuidadosa e crítica, indica a temática enfrentada pelas autoras e analisa cada uma delas com agudez:

[...] a produção literária das mulheres, vista como um fenômeno específico no movimento literário ou cultural em geral, vem exigindo da crítica uma atenção especial. Não se trata (como muitos, erroneamente, pensam) de julgar se a literatura "feminina" é melhor ou pior do que a "masculina". Obviamente, tais discussões não têm sentido, pois já é ponto pacífico o fato de que valor literário não tem sexo. Tanto há os grandes escritores ou escritoras como os meramente bons, medíocres ou péssimos. $\mathrm{O}$ confronto entre ambas as produções leva facilmente à conclusão de que homens e mulheres se igualam em força ou energia criativa, desde que tenham iguais oportunidades de desenvolvimento cultural, e de que a maior ou menor densidade literária de cada obra depende exclusivamente do maior ou menor grau de qualidade do espírito que a produz, seja de homens, seja de mulheres. (COELHO, 2000, p. 89, 90)

A produção de Nelly nessas duas áreas mostra a necessidade de se trabalhar a relação entre Literatura e contexto histórico. De acordo com ela, a trajetória histórica permite ao crítico avaliar o presente pelo "ontem" e, então, fazer as projeções para o "amanhã". Sua obra Panorama Histórico da Literatura Infantil e Juvenil atesta esse olhar articulador entre sincronia e diacronia no trato com a Literatura.

\section{0 desafio da crítica literária}

O apurado olhar analítico sobre o texto literário levou a professora Nelly Novaes Coelho a colaborar em periódicos brasileiros e portugueses, muito cedo. A atividade 
Linha D'Água (Online), São Paulo, v. 30, n. 2, p. 9-16, out. 2017

teve início nos anos 60, quando esse espaço era exclusivamente masculino e pouquíssimas mulheres eram reconhecidas como escritoras ou tinham voz na crítica4:

Comecemos por dizer que, no âmbito geral da Literatura. Um dos problemas mais difíceis de resolver é o da crítica. Difícil porque o ato crítico é, por natureza, ato de cúpula: é o último a surgir no processo de criação, produção e desenvolvimento de qualquer literatura. Último por que, sendo a crítica uma reflexãosíntese do fenômeno literário, uma espécie de "iluminação" do que nele é valor ou desvalor (como criação literária ou em relação ao objetivo visado), ela necessariamente precisa partir de conhecimentos a priori que a orientem na análise, interpretação e conclusão (ou julgamento). (COELHO, 2000, p. 145)

Além da crítica, muitos foram os ensaios e artigos de sua autoria publicados no Suplemento Literário do jornal O Estado de S. Paulo, mídia com a qual colaborou entre os anos de 1961 a 1971.

Em 2013, concretizou-se mais um audacioso projeto da pesquisadora, Escritores Brasileiros do Século XX: um testamento crítico. Essa obra, publicada pela Editora LetraSelvagem, apresenta, em 975 páginas, minuciosa biografia e análise dos romances de cada um dos oitenta autores selecionados.

A última produção da professora Nelly Novaes Coelho foi a homenagem à colega de trabalho na área de Literatura Infantil e Juvenil da USP - a professora Dra. Maria Lúcia Pimentel de Sampaio Góes (*1934) Tecendo Literatura entre vozes e olbares, publicada pela Editora Humanitas, em 2015.

A extensa atuação no Brasil e em Portugal fez de Nelly Novaes Coelho detentora de premiações e homenagens, entre os quais citamos: Prêmio Bocage (1966), pelo Min. Educação Lisboa, ex.aequo Dra. Maria Helena da Rocha Pereira; Prêmio Jabuti/ Ensaio (1974), pela Câmara Brasileira do Livro; Prêmio/Ensaio (1975), pela Associação Paulista de Críticos de Arte; Prêmio Especial da Crítica -30 anos de crítica literária (1983), Instituto Internacional Ibero-Americano/ USA (1988); pela Associação Paulista de Crítica de Arte; Associação Paulista de Críticos de Arte APCA (Presidente/1990); Prêmio "Professor-Destaque" (1991), homenagem prestada pelo DD. Reitor Roberto Lobo e Silva, da Universidade de

$4 \quad$ Nas palavras da própria Nelly Novaes Coelho.

CUNHA, M. Z.; LOPES, C. C. Nelly Novaes Coelho: uma vida dedicada à Literatura 
Linha D'Água (Online), São Paulo, v. 30, n. 2, p. 9-16, out. 2017

São Paulo; Prêmio Clara Ramos (1997), pela União Brasileira de Escritores, RJ; Título de Comendadora por mérito cultural (1998), pela Universidade Minhota - Pólo Barcelos/Minho /Portugal; Prêmio Jaburu - Personalidade do ano (1998), pelo Conselho Estadual de Cultura do Governo de Goiás; Sala Nelly Novaes Coelho (2007), homenagem da Diretoria das Bibliotecas Públicas do Estado de São Paulo/ Secretaria de Cultura de São Paulo.

\section{0 século XXI e as transformações do mundo}

Pode-se notar a respeito desse confronto que a humanidade se transforma ciclicamente: o paradigma emergente, a partir de certo momento, é instaurado; com o tempo consolida-se, dá frutos, alavanca o progresso e acaba por criar um novo homem, que passa a não caber nos limites daquele "paradigma" inicial. Este, devido ao seu próprio sucesso e progresso, acaba sendo superado. Grosso modo, esse é o fenômeno que se instaurou no mundo ocidental a partir do início do século XX, com o esgotamento irredutível da brilhante e progressista sociedade que se consolidou no século XIX, a que herdamos como tradição e entre cujos escombros continuamos a viver, até que uma nova ordem se imponha. (COELHO, 2000, p. 137)

Sagaz e sabedora do complexo momento de profundas transformações que vivemos, Nelly asseverava que os conhecimentos a priori não mais se mantém confiáveis como parâmetros seguros para avaliar os valores que se encontram em mutação. Nesse contexto, dizia ela, são esses valores em mutação que devem se colocar na mira dos professores, pesquisadores e críticos, abrindo caminhos para o estudo da obra literária em sua sintonia com o tempo a que pertence. Não podemos alterar as circunstâncias de nosso tempo, dizia nossa professora, mas devemos nos tornar conscientes dela. Há muitos índices a serem perseguidos em obras aparentemente ingênuas e muita complexidade a ser desvendada em obras aparentemente pueris. Para ela, do encontro com a palavra literária poderá vir uma conscientização para o homem da pós-modernidade, capaz de fazê-lo ver-se como ser de linguagem capaz de renomear o mundo. Saber transformar a palavra literária em caminhos de conhecimento do mundo, base para o reencontro do ser humano com os outros e consigo mesmo foi o que Nelly - pesquisadora, professora, ensaísta, orientadora generosa e otimista - demonstrou ao longo de seu trabalho em todos os níveis em 
Linha D'Água (Online), São Paulo, v. 30, n. 2, p. 9-16, out. 2017

que atuou. Nelly afirmou: "literatura são experiências humanas transformadas em linguagem". Efetivamente, ela sempre colocou em prática sua convicção, renovando o compromisso de orientar agentes de transformação.

\section{Produção bibliográfica}

Tempo, solidão e morte (1964)

O ensino da literatura (1966)

Literatura e linguagem (1974)

Literatura infantil-Teoria, análise, didática (1981)

Dicionário crítico da literatura infantil/juvenil (1983)

Panorama histórico da literatura infantil/juvenil (1984)

O conto de fadas - símbolos, mitos, arquétipos (1987)

A literatura feminina no Brasil contemporâneo (1993)

Literatura: arte, conhecimento e vida (2000)

Dicionário crítico de escritoras brasileiras (2002/2011)

Escritores brasileiros do século XX: um testamento crítico (2013)

Tecendo literatura entre vozes e olhares (2015)

\section{Referências}

COELHO, Nelly Novaes. Literatura Infantil: Teoria, Análise, Didática. São Paulo: Moderna, 2000. Literatura: arte, conhecimento e vida. São Paulo: Peirópolis, 2000.

PAPES, Cleide. A palavra de NELLY NOVAES COELHO. Revista Crioula, São Paulo, n. 7, may 2010. ISSN 1981-7169. Disponível em: <https://www.revistas.usp.br/crioula/article/ view/55267/58896>. Acesso em: 02 out. 2017. doi:http://dx.doi.org/10.11606/issn.1981-7169. crioula.2010.55267. 